\title{
Upregulation of T-Cell-Specific Transcription Factor Expression in Pediatric T-Cell Acute Lymphoblastic Leukemia (T-ALL)
}

\author{
Pediatrik T-Hücreli Akut Lenfoblastik Lösemide (T-ALL) T-Hücrelerine \\ Özgü Transkripsiyon Faktörlerinin Artmış Gen Anlatımları
}

Müge Sayitoğlu ${ }^{1}$, Yücel Erbilgin ${ }^{1}$, Özden Hatırnaz $\mathrm{Ng}^{1}$, İnci Yıldız ${ }^{2}$, Tiraje Celkan², Sema Anak ${ }^{3}$, Ömer Devecioğlu ${ }^{3}$, Gönül Aydoğan ${ }^{4}$, Serap Karaman ${ }^{5}$, Nazan Sarper ${ }^{6}$, Çetin Timur ${ }^{7}$, Ümit Üre ${ }^{8}$, Uğur Özbek ${ }^{1}$

${ }^{1}$ Istanbul University, Department of Genetics, Institute of Experimental Medicine, İstanbul, Turkey

${ }^{2}$ İstanbul University, Cerrahpaşa School of Medicine, Department of Pediatric Hematology, İstanbul, Turkey

${ }^{3}$ İstanbul University, İstanbul School of Medicine, Department of Pediatric Hematology, İstanbul, Turkey

${ }^{4}$ Bakırköy Maternity and Children's Hospital, Department of Pediatrics, İstanbul, Turkey

${ }^{5}$ Ministry of Health Sissli Etfal Teaching Hospital, Department of Pediatric Hematology, İstanbul, Turkey

${ }^{6}$ Kocaeli School of Medicine, Department of Pediatric Hematology, Kocaeli, Turkey

${ }^{7}$ Ministry of Health Göztepe Teaching Hospital, Department of Pediatric Hematology, İstanbul, Turkey

${ }^{8}$ Ministry of Health Bakırköy Sadi Konuk Teaching Hospital, Department of Hematology, İstanbul, Turkey

\begin{abstract}
Objective: T-cell acute lymphoblastic leukemia (T-ALL) is associated with recurrent chromosomal aberrations and abnormal ectopic gene expression during T-cell development. In order to gain insight into the pathogenesis of T-ALL this study aimed to measure the level of expression of 7 T-cell oncogenes (LMO2, LYL1, TAL1, TLX1, TLX3, BMI1, and CALM-AF10) in pediatric T-ALL patients.

Material and Methods: LMO2, LYL1, TLX1, TLX3, BMI1, TAL1, and CALM-AF10 expression was measured using quantitative real-time PCR in 43 pediatric T-ALL patients.

Results: A high level of expression of LMO2, LYL1, TAL1, and BMI1 genes was observed in a large group of T-ALL. Several gene expression signatures indicative of leukemic arrest at specific stages of normal thymocyte development (LYL1 and LMO2) were highly expressed during the cortical and mature stages of T-cell development. Furthermore, upregulated TAL1 and BMIl expression was observed in all phenotypic subgroups. In all, 6 of the patients had TLX1 and TLX3 proto-oncogene expression, which does not occur in normal cells, and none of the patients had CALM-AF10 fusion gene transcription. Expression of LYL1 alone and LMO2-LYL1 co-expression were associated with mediastinal involvement; however, high-level oncogene expression was not predictive of outcome in the present pediatric T-ALL patient group, but there was a trend towards a poor prognostic impact of TAL1 and/or LMO2 and/or LYL1 protooncogene expression.
\end{abstract}

Address for Correspondence: Uğur ÖZBEK, M.D.,

İstanbul Universitesi, Deneysel Tıp Araştırma Enstitüsü, Genetik Anabilim Dalı, İstanbul, Turkey

Phone: +90 2124142200 E-mail: uozbek@istanbul.edu.tr

Received/Geliş tarihi : October 26, 2010

Accepted/Kabul tarihi : February 21, 2012 
Conclusion: Poor prognostic impact of TAL1 and/or LMO2 and/or LYL1 proto-oncogene expression indicate the need for extensive study on oncogenic rearrangement and immunophenotypic markers in T-ALL, and their relationship to treatment outcome.

Key Words: T-ALL, Pediatric, Transcription factor, Expression, Prognosis

Özet

Amaç: T-hücreli akut lenfoblastik lösemi (T-ALL), tekrarlı kromozom bozuklukları ve T-hücre gelişim basamaklarındaki anormal ektopik gen anlatım profili ile ilişkilidir. T-ALL patogenezine eğilebilmek için, çocukluk çağı T-ALL hastalarında, yedi farklı T-hücre onkogenlerinin anlatım düzeylerini belirlemeyi hedefledik (LMO2, LYL1, TAL1, TLX1, TLX3, BMI1 ve CALM-AF10).

Gereç ve Yöntemler: Çocukluk çă̆ı T-ALL hastalarında (n=43) LMO2, LYL1, TLX1, TLX3, BMI1, TAL1, CALM-AF10 gen ekspresyonlanı kantitatif eş zamanlı PCR yöntemi ile tespit edildi.

Bulgular: T-ALL hastalarının büyük çoğunluğunda, artmış LMO2, LYL1, TAL1 ve BMI1 gen anlatımları belirlendi. Normal timosit gelişiminin spesifik basamaklarındaki lösemik tutulumu gösteren genlerden olan LYL1 ve LMO2' nin artmış ekspresyonu kortikal ve olgun timosit gelişim basamaklarında gözlendi. Bunun yanı sıra, artmış TAL1 ve BMII ekspresyonlanı bütün fenotipik alt gruplarda belirlendi. Altı hastada, normal koşullarda anlatımı görülmeyen TLXı ve TLX2 gen anlatımları mevcut iken, hastalarımızın hiçbirinde CALM-AF10 füzyon gen transkripti belirlenmedi. Onkogen ekspresyonları ile klinik verileri karşılaştırdığımızda ise LYL1 ve LMO2-LYL1 genlerinin beraber anlatımları mediasten tutulumu ile ilişkili bulundu. Ancak, yüksek onkogen ekspresyonları pediatrik T-ALL grubumuzda hastaların son durumlarının önceden tahmin edilebilmesi açısından anlamlı değildir. Ama TALl ve/veya LMO2 ve/veya LYL1 gen ekspresyonlarının kötü prognozla ilişkili olabileceğine dair bir eğilimden bahsedebiliriz.

Sonuç: TAL1 ve/veya LMO2 ve/veya LYL1 gen ekspresyonlarının kötü prognozla olan ilişkisi, onkogenik yeniden düzenlenmeler ve immünfenotipik belirteçlerle beraber, daha büyük çalışma gruplarında çalışılması ve hastanın son durum ile olan ilişkisinin ortaya çıkarılması, gelecekteki tedavi protokolleri için önem arz etmektedir.

Anahtar Sözcükler: T-ALL, Pediatrik, Yazılım faktörü, Gen anlatımı, Prognoz

\section{Introduction}

T-cell acute lymphoblastic leukemia (T-ALL) is a rare, aggressive malignancy of thymocytes and corresponds to a heterogeneous group of leukemia arrested at various stages of lymphoid development. T-ALL constitutes 15\% of all childhood ALL and 25\% of adult ALL; approximately 30\% of patients relapse within the first year of treatment and the outcome is usually death [1]. T-ALL patients characteristically have recurrent and rare cytogenetic alterations that affect the gene expression profile of involved genes. These proto-oncogenes are associated with the pathways involved in T-cell development, such as differentiation, proliferation, survival, the cell cycle, and self-renewal. Most chromosomal translocations associated with T-ALL result in juxtaposition of T-cell antigen receptor (TCR) loci $(\alpha / \delta$ or $\beta)$ regulatory elements to proto-oncogenes, thus deregulating expression of the latter [2]. TCR promoters and enhancers are juxtaposed to a number of developmentally important transcription factor genes, including HOX11/TLX1, TLX3/HOX11L2, TAL1/SCL, TAL2, LYL1, bHLHB1, LMO1, and LMO2. Deregulation of these genes primarily arrest differentiation at specific stages of T-cell development [3-7].

TAL1, TAL2, LYL1, and bHLHB1 genes are part of the basic helix-loop-helix (bHLH) protein family and function as transcriptional co-factors that form complexes with E2A/ HEB. bHLH protein family members also bind to members of the LMO gene family. During normal human T-cell development, TAL2 and LMO1 are not expressed, whereas Lyl1, Tal1, and Lmo2 expression in mice are restricted to the earliest double-negative stages of T-cell maturation. TLX1 is a class II homeobox gene normally involved in spleen development that is not activated during normal T-cell development. TLX1-positive T-ALL cases share a similar gene expression profile characterized by arrest at the early cortical, CDl-positive thymocyte stage. Translocation/ectopic expression of these transcription factors have been reported with different percentage in pediatric T-ALL $[8,9]$. More recently, evidence of NOTCH1 mutations in $25 \%-50 \%$ of pediatric T-ALL patients has further enhanced the biologic heterogeneity of T-ALL $[10,11]$. An alternative mechanism of increased NOTCH1 activation 
via loss-of-function mutations of FBWX7 leads to inhibition of ubiquitin-mediated degradation of the activated form of NOTCH1 [12].

These transcription factors and their oncogenicity have been well documented in mouse models; however, few of these known oncogenetic markers have been shown to have prognostic significance in humans. Conflicting outcomes have been associated with TLX3 and TAL1 deregulation, and NOTCH1 mutations. TLX1-positive T-ALL patients frequently have activating NOTCH1 mutations, and TLX1 over expression and/or translocation confers a better prognosis, but this association varies by study [13-16]. In an earlier study we determined the NOTCH1 and FBXW7 mutation status in a pediatric T-ALL cohort [10]. In the present study we examined the transcription factor genes LMO2, LYL1, TAL1, TLX1, TLX3, and BMI1, and gene fusion of CALM-AF10 in an effort to identify T-cell-specific oncogenic transcription factors and their association with prognosis in pediatric T-ALL patients.

\section{Materials and Methods}

\section{Participants}

At the time of diagnosis of T-ALL, bone marrow (BM) $(\mathrm{n}=33)$ and peripheral blood $(\mathrm{PB})(\mathrm{n}=10)$ samples were obtained from 43 pediatric patients. The study included pediatric T-ALL patients diagnosed at Istanbul University, Cerrahpaşa School of Medicine $(\mathrm{n}=15)$ and Istanbul School of Medicine ( $\mathrm{n}=12)$, Bakirköy Maternity and Children's Hospital ( $\mathrm{n}=5)$, Ministry of Health Şişli Etfal Teaching Hospital ( $\mathrm{n}=5)$, Kocaeli University, Kocaeli School of Medicine $(n=2)$, Ministry of Health Göztepe Teaching Hospital ( $\mathrm{n}=2)$, and Ministry of Health Haseki Teaching Hospital $(\mathrm{n}=2)$. Patients were diagnosed based on French-American-British (FAB) Group criteria and their clinical characteristics are shown in Supplemental Table 1 [17]. Mean age of the 17 female and 26 male patients was $8.8 \pm 4.1$ years, and the median white blood cell (WBC) count was $68,400 \times 10^{9} / \mathrm{L}$ (range: $1300-580,000 \times 10^{9} / \mathrm{L}$ ). In all, 20 of the patients were in complete remission (CR), 14 died, and 9 were lost to follow-up. T-ALL subgroups were classified according to European Group for the Immunological Characterization of Leukemias (EGIL) guidelines, as follows: immature: $\mathrm{n}=16$; cortical: $\mathrm{n}=8$; mature: $\mathrm{n}=11$ [18]. All T-ALL patients received chemotherapy, according to the Turkish ALL-Berlin-Frankfurt-Munster (Turkish BFM) protocol. Patients were already screened for NOTCH1 and FBXW7 mutations (Supplemental Table 2) $[10]$

Anonymous control thymocyte subsets were obtained from pediatric thymus tissues, using the same guidelines described for T-ALL subgroup classification [19]. Sorted CD34+ CD38- CDla-, CD34+ CD38+ la-, CD34+ CD38+ la+, ISP (immature single positive), DP (double positive) CD3-, DP CD3+, SP (single positive), CD4+, and SP CD8+ cells were used as T-cell stage specific controls. Thymus cells were kindly provided by Dr. Frank J.T. Staal, Erasmus Medical Center, Department of Immunology, Rotterdam, The Netherlands. The Istanbul School of Medicine Ethics Committee (reference number and date: 2008/305 and 20.02.2008) approved the study protocol and informed consent was provided by all the patients.

\section{cDNA synthesis and quantitative real-time PCR (QRT-PCR)}

Total RNA was isolated using a Qiagen RNeasy Plus Mini Kit (Qiagen, GmbH, Germany), so as to eliminate the genomic DNA prior to RNA isolation. RNA quality and quantity were measured using a Nanodrop 1000 (Thermo Fisher Scientific, Germany), and cDNA was synthesized from $1 \mu \mathrm{g}$ of total RNA using a random hexamer and MMLV reverse transcriptase, according to the enzyme manufacturer's instructions (MBI Fermentase Life Sciences, Lithuania). Quantitative real-time PCR (QRT-PCR) was performed using an ABI 7700 (Applied Biosytems, Foster City, CA, USA) with specific primer-probes, as described by van Grotel et al. [20]. The level of expression of LMO2, LYL1, TLX1, TLX3, BMI1, TAL1, and CALM-AF10 was normalized to $A B L$ gene expression. The threshold value, which is the maximum level of expression of each of the normal thymic subsets, was evaluated for each gene.

\section{Statistical analysis}

Relative gene expression was calculated according to the delta-delta $\mathrm{Ct}$ method-based mathematical model [21]. Analyzed gene expression was categorized as high and low, as compared to controls. Categorical variables were compared using Fisher's exact test and comparison of medians was performed using the Mann-Whitney U test. Remission status was assessed after completion of induction chemotherapy. Treatment efficacy was analyzed according to in vivo response to induction therapy on $\mathrm{d}$ 33 ( $<5 \%$ BM blasts). Based on the 33-d response, patients were classified as good ( $<5 \%$ BM blasts) and poor $(>5 \%$ BM blast) responders. CR was defined as the absence of leukemic blasts in the peripheral blood and cerebrospinal fluid, $<5 \%$ lymphoblasts in BM aspiration smears, and no evidence of localized disease. Primary treatment failure was defined as persistence of PB blasts or $\geq 25 \%$ blasts in BM after induction therapy. Relapse was defined as the 
reappearance of $\mathrm{PB}$ blasts, $>5 \%$ blasts in $\mathrm{BM}$, or the appearance of extramedullary manifestations after CR was achieved.

The Kaplan-Meier method was used to estimate survival rates. Median follow-up was 13.28 months (range: 1-130 months). Overall survival (OS) was defined as the interval from the date of diagnosis to the date of last follow-up or death. Relapse-free survival (RFS) was the time from the start of CR to the date of analysis or to the first event (failure to achieve remission - early death or resistant leukemia-, relapse or death in complete remission). Differences were compared using the 2-sided log-rank test. Mul- tivariate survival analysis was estimated according to the Cox regression model, and included the variables of gene expression, gender, age, WBC count, and immunophenotype. The level of statistical significance was set at $\mathrm{P}=0.05$. Statistical analysis was performed using SPSS v.12.0 for Windows (SPSS, Inc, Chicago, IL, USA)

\section{Results}

\section{Up-regulated oncogene expression found in pediatric T-ALL patients}

The patients were grouped according to EGIL criteria (immature, cortical, and mature stages) and the levels of

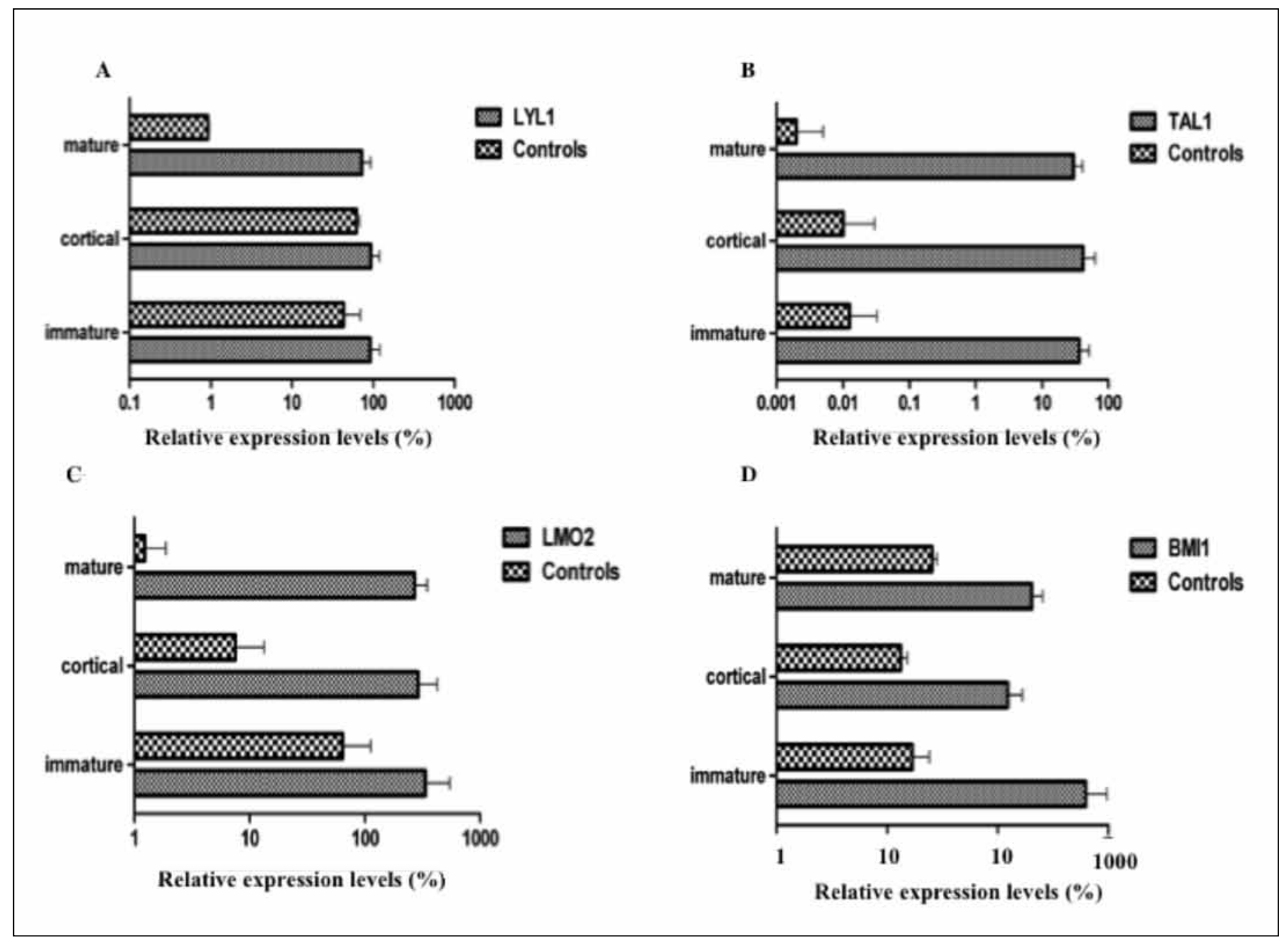

Figure 1: QRT-PCR analysis of oncogenes in the pediatric T-ALL patient subgroups (according to EGIL criteria) and normal thymic control subsets. A. LYLl expression was significantly higher in the cortical and mature stage subgroups, as compared to their specific controls (cortical versus control: $\mathrm{P}=0.02$; mature versus control: $\mathrm{P}=0.007$ ). B. TALl expression was significantly higher in all the phenotypic subgroups than in the controls (immature versus control: $\mathrm{P}=0.01$; cortical versus control: $\mathrm{P}=0.01$; mature versus control; $\mathrm{P}=0.02$ [Mann-Whitney U test]). C. LMO2 expression was significantly higher in the cortical and mature stage subgroups than in the controls (cortical versus control: $\mathrm{P}=0.05$; mature versus control: $\mathrm{P}=0.007$ ). $\mathrm{D}$. BMIl expression was higher in all the phenotypic subgroups than in their specific controls (immature versus control: $\mathrm{P}=0.01$; cortical versus control: $\mathrm{P}=0.01$; mature versus control: $\mathrm{P}=0.01$ ). 
gene expression were compared to normal thymic subsets. A group of patients had an up-regulated gene expression profile for LYL1, TAL1, and LMO2. In all, 25 of 41 patients (60.9\%) had high-level TAL1 gene expression, 30\% of the 43 T-ALL patients had LMO2 overexpression, and 10 patients (25.6\%) had a high level of LYL1 gene expression, as compared to the controls. Individual gene expression levels did not significantly differ between the T-ALL phenotypic subgroups (immature, cortical, and mature). Comparison of the phenotypic subgroups and their stagespecific counterparts showed that LYL1 expression was significantly higher both in the cortical and mature stage subgroups than in their specific controls $(\mathrm{P}=0.02$ and $\mathrm{P}$ $=0.007$, respectively), TAL1 expression was significantly higher in all the phenotypic subgroups (immature versus control: $\mathrm{P}=0.01$; cortical versus control: $\mathrm{P}=0.01$; mature versus control: $\mathrm{P}=0.02$ [Mann-Whitney $\mathrm{U}$ test]), and LMO2 expression was significantly higher in the cortical and mature stage subgroups $(\mathrm{P}=0.05$ and $\mathrm{P}=0.007$, respectively) (Figure 1A-C). LYL1 and TAL1 co-expression was significantly higher in the cortical $(\mathrm{P}=0.008$ [MannWhitney $\mathrm{U}$ test $)$ and immature $(\mathrm{P}=0.01)$ stage subgroups.

Three of the patients had TLX1 expression and 3 others had TLX3 expression. BMI1 expression was observed in all of the patients and $53.4 \%$ of the 43 patients exhibited over-expression, as compared to the controls. BMI1 expression was higher in all the phenotypic subgroups, as compared to their specific counterparts (immature versus control: $\mathrm{P}=0.01$; cortical versus control: $\mathrm{P}=0.01$; mature versus control: $\mathrm{P}=0.01$ [Mann-Whitney $\mathrm{U}$ test]) (Figure 1D). One of the recurrent translocations in T-ALL patients is $\mathrm{t}(10 ; 11)(\mathrm{pl} ;$; $14-21)$, which results in the CALM-AF10 fusion transcript; none of the pediatric patients were carrying CALM-AF10 fusion.

\section{Oncogene expression and outcome in the pediatric T-ALL patients}

To assess the prognostic significance of the above findings we compared the levels of oncogene expression and patient clinical characteristics, and then analyzed survival in the T-ALL patients. High-level LYL1 expression was correlated with mediastinal masses $(P=0.01)$ and other organ involvement $(\mathrm{P}=0.04)$. LMO2-LYL1 co-expression was strongly associated with mediastinal involvement ( $\mathrm{P}$ $=0.02$ [Fisher's exact test]). The patients with TLX1 expression had mediastinal masses ( $\mathrm{P}=0.003$ [Fisher's exact test]) and TLX1 expression was correlated with organ involvement, including the kidneys and heart $\mathrm{P}=0.05$ [Fisher's exact test]). TLX3 expression was associated with central nervous system (CNS) involvement $(\mathrm{P}=0.04$ [Fisher's exact test]).

Preliminary comparison of the Kaplan-Meier plots showed that there wasn't a significant difference between the individual oncogene expression groups, except for the TLX3 gene (patients with high-level TLX3 expression versus patients with no or low-level expression [Cox regression <0.0001; 95\% CI: 1.6-18.6]). Additionally, we combined the oncogenes, such as TAL1 and/or LMO2 and/or LYL1, TLX1 and TLX3, TAL1 and/or LMO2 and/or LYL1 and/or TLX1, and TLX3 and/or BMI1. The outcome of these synergistic subgroups versus patients with normal expression of the oncogenes did not reach the level of statistical significance (Figure 2); however, the obtained data showed a trend toward longer RFS in the patients with normal TAL1 and/or LMO2 and/or LYL1 expression ( $\mathrm{P}=0.08$ [Mantel-Cox test]). NOTCH1/FBXW7 mutations were observed in all the genetic subgroups (Supplemental Table 2). Although significant differences were not observed in RFS or OS between the NOTCH1/FBXW7 wild-type and mutated cases, as previously described, we noted a trend toward longer RFS in the mutant patients (Supplemental Figure 1) [10]. Hence, we considered NOTCH1/FBXW7 mutation to be a marker of good prognosis and re-analyzed the survival data for the oncogene expressions. As a result, we observed an independent correlation between a high oncogene expression profile and short OS and RFS both in NOTCH1/FBXW7 mutants and wild-type groups, even it did not show a significant difference.

\section{Discussion}

Deregulation of signaling pathways that control normal T-cell development in the thymus plays a crucial role in T-ALL leukemogenesis. These pathways-under normal circumstances-are strictly regulated by transcription factors, which are also proto-oncogenic proteins. A few molecular mechanisms suggested for T-ALL pathogenesis including the mutations in NOTCH1 and FBXW7 genes leading to NOTCH pathway activation and ectopic expressions of the specific transcription factors such as LYL1, TAL1, LMO2, TLX genes. Currently, there are no genetic markers that can be used to reliably predict treatment response and/or outcome in pediatric T-ALL patients [22].

LMO2, LYL1, and TAL1 genes are members of the bHLH protein family. Among the phenotypic subgroups in the present study (immature, cortical, and mature), LYL1 and LMO2 exhibited the highest level of expression in immature cases, as reported by Meijerink et al. [23]. 
A)

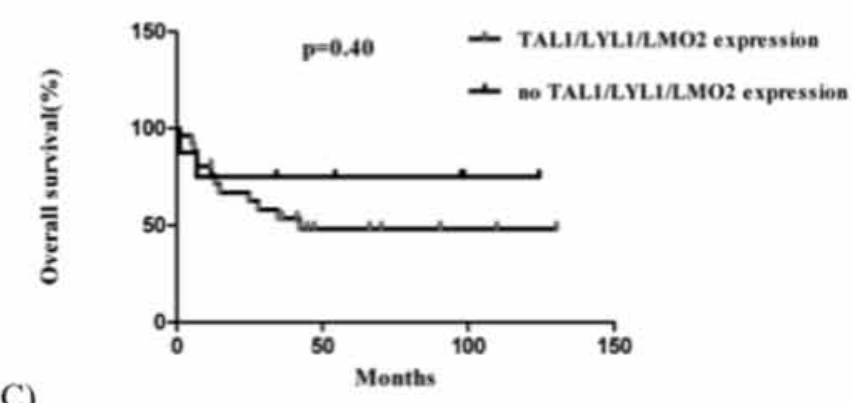

C)

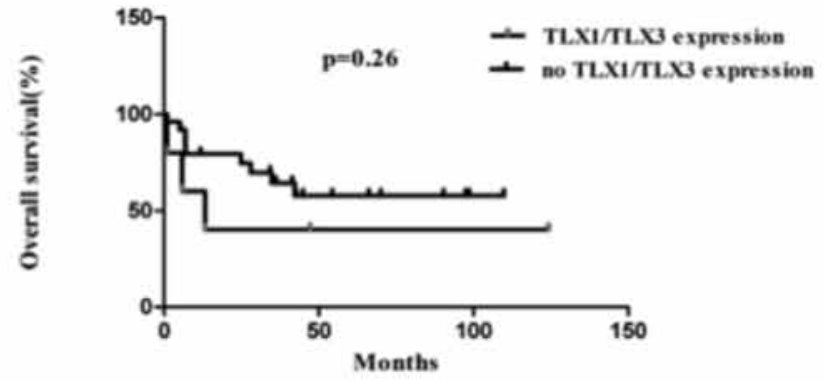

E)

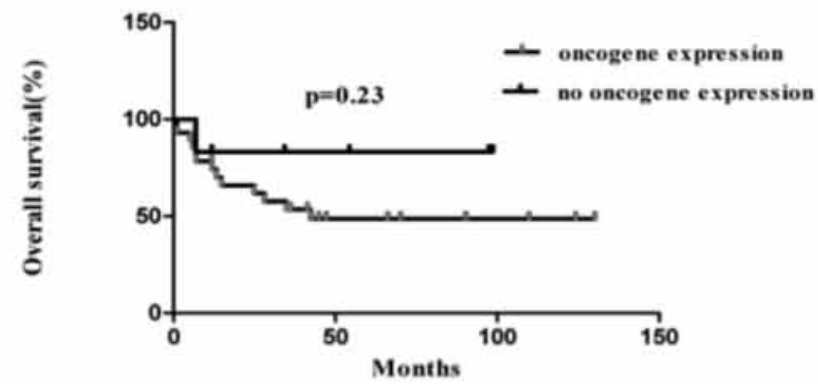

B)

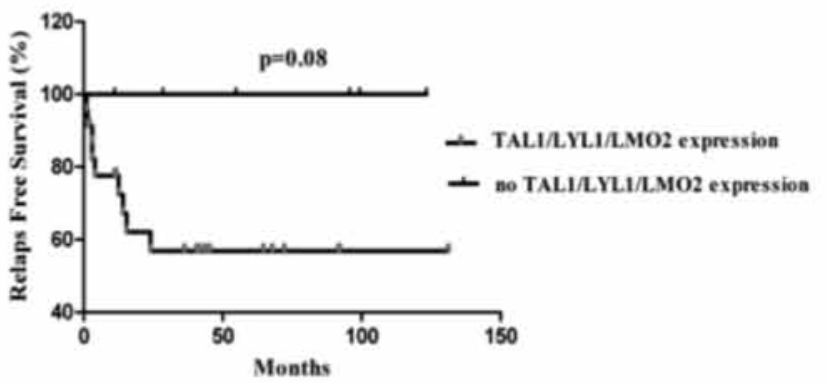

D)

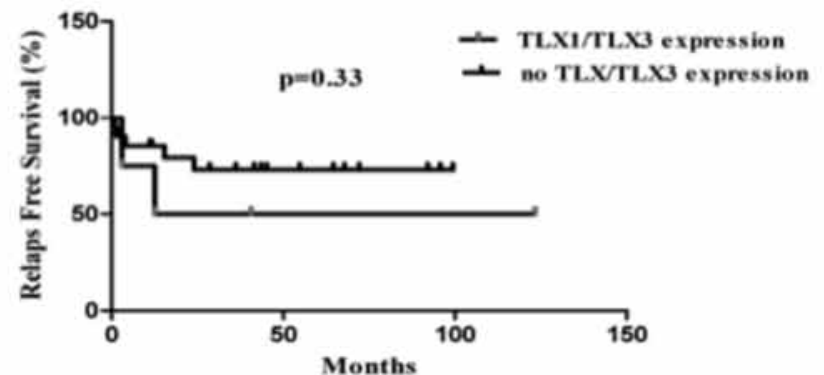

F)

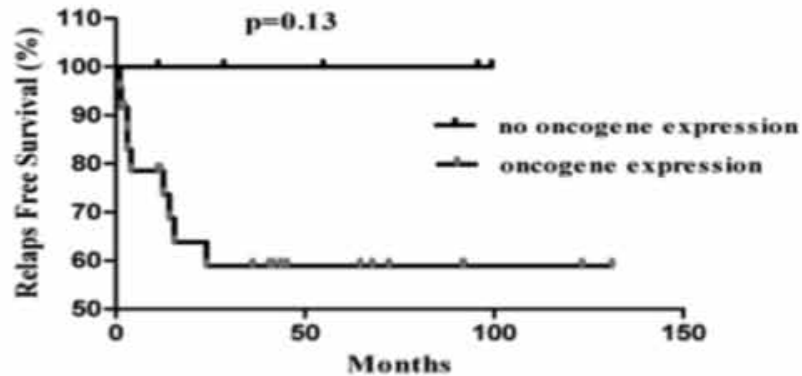

Figure 2: Outcome in pediatric T-ALL patients treated with the Turkish-BFM protocol. A. OS according to TAL1/LYL1/LMO2 expression. B. RFS according to TAL1/LYL1/LMO2 expression. C. OS according to TLX1/TLX3 expression. D. RFS according to TLX1/ TLX3 expression. E. OS according to TAL1/LYL1/LMO2/TLX1/TLX3/BMI1 expression. F. RFS according to TAL1/LYL1/LMO2/ TLX1/TLX3/BMI1 expression. P value $\leq 0.05$ (two sided) was considered indicative of a statistically significant difference. None of the Kaplan-Meier analyses showed significant differences.

Recognition of specific T-cell developmental subgroups may have prognostic relevance in T-ALL. Among pediatric T-ALL patients, a pro-T immunophenotype was strongly correlated with poorer outcome than other T-cell phenotypes [24]. In contrast, comparison of LYL1 and LMO2 gene expression with their specific counterparts in the present study showed that the most significant differences occurred in mature stage cases. Moreover, LYL1 alone and LMO2-LYL1 co-expression were strongly associated with mediastinal involvement. We classified gene expression in the cases as TAL1/LYL1/LMO2 up-regulated or normal (Figure 2A and B), and analyzed the Kaplan-Meier estimates of OS and RFS. Although it was not significant but TAL1/LYL1/LMO2 up-regulated patients showed poor RFS rates. To date, it is unclear if TAL1/LYL1/LMO2 expression can be used to predict treatment outcome, although some studies suggest that it can [25].

The CALM-AF10 (MLLT10) fusion gene $\mathrm{t}(10 ; 11)$ (p13;q21) is a common transcript in acute leukemia. It has been reported that $9 \%$ of adult T-ALL patients have 
CALM-AF10 fusion and it is restricted to immature lineage [26]. CALM-AF10-positive ALL is associated with TLX family members and their transcriptional regulator, BMII [26]. The BMI1 gene determines the proliferation capacity of normal and leukemic stem cells [27]. In the present study none of the T-ALL patients carried the CALM-AF10 fusion gene, whereas $53.4 \%$ of the cases had elevated BMI1 mRNA levels. Increased BMI1 expression in pediatric T-ALL cases is generally ectopic and independent of CALM-AF10 fusion. It was also suggested that up-regulated expression of BMI1 is responsible for the aggressive nature of T-ALL. Although a specific relationship between the present patient's clinical features and high-level BMII expression was not observed, T-ALL is the most aggressive form of ALL.

TLX genes are normally not expressed in adult tissues [28]. Approximately 7\%-20\% of childhood T-ALL patients have ectopic TLX1 and TLX3 expression $[15,16]$. In the present study $12 \%$ of the patients had ectopic expression of TLX1 and TLX3. Some studies indicate that ectopic TLX1 or TLX3 expression confers a poor response to treatment, whereas others report that they do not $[5,13]$. All the present study's patients with TLX1 expression had mediastinal masses and those with TLX3 expression had significant CNS involvement, which may consider a possibility of poor prognosis. TLX gene expression may figure out TLX1 or TLX3 translocations but unfortunately these patients lack of cytogenetic data to validate.

NOTCH1 activating mutations occur in 30\%-60\% of T-ALL patients $[10,11]$. Additionally, inactivating mutations in the E3-ubiquitin ligase gene FBXW7 contribute to aberrant expression of NOTCH1. TLX1 and NOTCH was reported to be synergistically activated to regulate transcription in T-ALL [29]. These mutations were observed in all the present study's genetic subgroups, but weren't correlated with oncogene expression or OS ans RFS, but the number of patients with TLX1 expression was insufficient for reaching any conclusion.

The present findings offer some clues about the effects of activated transcription factors in pediatric T-cell leukemogenesis, prognostic parameters, and therapeutic applications in different thymic subsets. The most significant finding of the present study is that deregulation of multiple transcription factors (LMO2, LYL1, TAL1, TLX1, TLX3, and BMI1) was involved in the differentiation of Tcells, which is in agreement with other reports [1-5]. The present findings are relevant to 3 main topics. The first is the etiological point of view that the development of pediatric T-ALL is associated with up-regulation of several oncogenic transcription factors in a stage-specific manner. T-cell-specific oncogene expression has a greater impact in mature stage patients than in immature stage patients. The second is the prognostic implication of which identification and validation of oncogenic transcription factors in T-cell leukemia may lead to the development of new prognostic markers; these may then be useful for patient follow-up in the future. Lastly, identification of specific expression profiles in pediatric T-ALL subgroups may aid the development of new therapeutic applications and protocols.

\section{Acknowledgments}

This study was funded by the Scientific and Technological Research Council of Turkey (TÜBITAK) (Project no: 106S112);

\section{Conflict of interest statement}

The authors of this paper have no conflicts of interest, including specific financial interests, relationships, and/ or affiliations, relevant to the subject matter or materials included.

\section{References}

1. Pui $\mathrm{CH}$, Relling MV, Downing JR. Acute lymphoblastic leukemia. N Engl J Med 2004; 350:1535-1548.

2. Cleary ML, Mellentin JD, Spies J, Smith SD. Chromosomal translocation involving the beta $\mathrm{T}$ cell receptor gene in acute leukemia. J Exp Med 1988;167:682-687.

3. Hatano M, Roberts CW, Minden M, Crist WM, Korsmeyer SJ. Deregulation of a homeobox gene, HOX11, by the $\mathrm{t}(10 ; 14)$ in T cell leukemia. Science 1991;253:79-82.

4. Bach I. The LIM domain: Regulation by association. Mech Dev 2000; 91:5-17.

5. Ballerini P, Blaise A, Busson-Le Coniat M, Su XY, ZucmanRossi J, Adam M, van den Akker J, Perot C, Pellegrino B, Landman-Parker J, Douay L, Berger R, Bernard OA. HOX11L2 expression defines a clinical subtype of pediatric T-ALL associated with poor prognosis. Blood 2002; 100:991-997.

6. Berger R, Dastugue N, Busson M, Van Den Akker J, Pérot C, Ballerini P, Hagemeijer A, Michaux L, Charrin C, Pages MP, Mugneret F, Andrieux J, Talmant P, Hélias C, Mauvieux L, Lafage-Pochitaloff M, Mozziconacci MJ, Cornillet-Lefebvre P, Radford I, Asnafi V, Bilhou-Nabera C, Nguyen Khac F, Léonard C, Speleman F, Poppe B, Bastard C, Taviaux S, Quilichini B, Herens C, Grégoire MJ, Cavé H, Bernard OA. t(5;14)/HOX11L2-positive T-cell acute lymphoblastic leukemia. A collaborative study of the Groupe Francais de Cytogenetique Hematologique (GFCH). Leukemia 2003;17:1851-1857. 
7. Aifantis I, Raetz E, Buonamici S. Molecular pathogenesis of T-cell leukaemia and lymphoma. Nat Rev Immunol 2008;8:380-390.

8. Grabher C, von Boehmer H, Look AT. Notch 1 activation in the molecular pathogenesis of T-cell acute lymphoblastic leukaemia. Nat Rev Cancer 2006;6:347-359.

9. Ferrando AA, Look AT. Gene expression profiling in T-cell acute lymphoblastic leukemia. Semin Hematol 2003;40:274-280.

10. Erbilgin Y, Sayitoglu M, Hatirnaz O, Dogru O, Akcay A, Tuysuz G, Celkan T, Aydogan G, Salcioglu Z, Timur C, Yuksel-Soycan L, Ure U, Anak S, Agaoglu L, Devecioglu O, Yildiz I, Ozbek U. Prognostic significance of NOTCH1 and FBXW7 mutations in pediatric T-ALL. Dis Markers 2010;28:353-360

11. Weng AP, Ferrando AA, Lee W, Morris JP 4th, Silverman LB, Sanchez-Irizarry C, Blacklow SC, Look AT, Aster JC. Activating mutations of NOTCH1 in human $\mathrm{T}$ cell acute lymphoblastic leukemia. Science 2004;306:269-271.

12. Malyukova A, Dohda T, von der Lehr N, Akhoondi S, Corcoran M, Heyman M, Spruck C, Grandér D, Lendahl U, Sangfelt $\mathrm{O}$. The tumor suppressor gene hCDC4 is frequently mutated in human T-cell acute lymphoblastic leukemia with functional consequences for Notch signaling. Cancer Res 2007;67:5611-5616.

13. Cavé H, Suciu S, Preudhomme C, Poppe B, Robert A, Uyttebroeck A, Malet M, Boutard P, Benoit Y, Mauvieux L, Lutz P, Méchinaud F, Grardel N, Mazingue F, Dupont M, Margueritte G, Pages MP, Bertrand Y, Plouvier E, Brunie G, Bastard C, Plantaz D, Vande Velde I, Hagemeijer A, Speleman F, Lessard M, Otten J, Vilmer E, Dastugue N. Clinical significance of HOX11L2 expression linked to $\mathrm{t}(5 ; 14)(\mathrm{q} 35 ; \mathrm{q} 32)$, of HOX11 expression, and of SIL-TAL fusion in childhood T-cell malignancies: Results of EORTC studies 58881 and 58951. Blood 2004;103:442-450.

14. Bergeron J, Clappier E, Radford I, Buzyn A, Millien C, Soler G, Ballerini P, Thomas X, Soulier J, Dombret H, Macintyre EA, Asnafi V. Prognostic and oncogenic relevance of TLX1/ HOX11 expression level in T-ALLs. Blood 2007;110:23242330.

15. Ferrando AA, Neuberg DS, Dodge RK, Paietta E, Larson RA, Wiernik PH, Rowe JM, Caligiuri MA, Bloomfield CD, Look AT. Prognostic importance of TLX1 (HOX11) oncogene expression in adults with T-cell acute lymphoblastic leukaemia. Lancet 2004;363:535-536.

16. Gottardo NG, Jacoby PA, Sather HN, Reaman GH, Baker DL, Kees UR. Significance of HOX11L2/TLX3 expression in children with T-cell acute lymphoblastic leukemia treated on Children's Cancer Group protocols. Leukemia 2005;19:1705-1708.
17. Lilleyman JS, Hann IM, Stevens RF, Eden OB, Richards SM. French American British (FAB) morphological classification of childhood lymphoblastic leukaemia and its clinical importance. J Clin Pathol 1986;39:998-1002.

18. Bene MC. Pro-T ALL: Immunophenotypical analyses. J Biol Regul Homeost Agents 2004;18:327-330.

19. Dik WA, Pike-Overzet K, Weerkamp F, de Ridder D, de Haas EF, Baert MR, van der Spek P, Koster EE, Reinders MJ, van Dongen JJ, Langerak AW, Staal FJ. New insights on human $\mathrm{T}$ cell development by quantitative $\mathrm{T}$ cell receptor gene rearrangement studies and gene expression profiling. J Exp Med 2005; 201:1715-1723.

20. van Grotel M, Meijerink JP, Beverloo HB, Langerak AW, Buys-Gladdines JG, Schneider P, Poulsen TS, den Boer ML, Horstmann M, Kamps WA, Veerman AJ, van Wering ER, van Noesel MM, Pieters R. The outcome of molecular-cytogenetic subgroups in pediatric T-cell acute lymphoblastic leukemia: A retrospective study of patients treated according to DCOG or COALL protocols. Haematologica 2006;91:1212-1221.

21. Pfaffl MW. A new mathematical model for relative quantification in real-time RT-PCR. Nucleic Acids Res 2001;29:45.

22. Look AT. E2A-HLF chimeric transcription factors in pro-B cell acute lymphoblastic leukemia. Curr Top Microbiol Immunol 1997;220:45-53.

23. Homminga I, Pieters R, Langerak AW, de Rooi JJ, Stubbs A, Verstegen M, Vuerhard M, Buijs-Gladdines J, Kooi C, Klous $\mathrm{P}$, van Vlierberghe P, Ferrando AA, Cayuela JM, Verhaaf B, Beverloo HB, Horstmann M, de Haas V, Wiekmeijer AS, Pike-Overzet K, Staal FJ, de Laat W, Soulier J, Sigaux F, Meijerink JP. Integrated transcript and genome analyses reveal NKX2-1 and MEF2C as potential oncogenes in T cell acute lymphoblastic leukemia. Cancer Cell 2011;19:484497.

24. Uckun FM, Gaynon PS, Sensel MG, Nachman J, Trigg ME, Steinherz PG, Hutchinson R, Bostrom BC, Sather $\mathrm{HN}$, Reaman GH. Clinical features and treatment outcome of childhood T-lineage acute lymphoblastic leukemia according to the apparent maturational stage of T-lineage leukemic blasts: A Children's Cancer Group study. J Clin Oncol 1997;15:2214-2221.

25. Meijerink JP. Genetic rearrangements in relation to immunophenotype and outcome in T-cell acute lymphoblastic leukaemia. Best Pract Res Clin Haematol 2010;23:307-318.

26. Dik WA, Brahim W, Braun C, Asnafi V, Dastugue N, Bernard OA, van Dongen JJ, Langerak AW, Macintyre EA, Delabesse E. CALM-AF10+ T-ALL expression profiles are characterized by overexpression of HOXA and BMII oncogenes. Leukemia 2005;19:1948-1957. 
27. Raaphorst FM. Self-renewal of hematopoietic and leukemic stem cells: A central role for the Polycomb-group gene Bmi1. Trends Immunol 2003;24:522-524.

28. De Keersmaecker K, Ferrando AA. TLX1 induced T-cell acute lymphoblastic leukemia. Clin Cancer Res 2011; 17:6381-6386.
29. Riz I, Hawley TS, Luu TV, Lee NH, Hawley RG. TLX1 and $\mathrm{NOTCH}$ coregulate transcription in $\mathrm{T}$ cell acute lymphoblastic leukemia cells. Mol Cancer 2010; 9:181.

\section{Supplemental Online Link:}

http://www.tjh.com.tr/file/Supplemental_ TurkJHematol_2012_29_325_333.pdf 